\title{
Culture Clash: A Case Study of Rover and BMW
}

\author{
Nerys Fuller-Love \\ School of Management and Business, University of Wales, Aberystwyth, SY23 3DW, UK
}

Tel: 07831232724 E-mail: nnf@aber.ac.uk

\begin{abstract}
This paper examines the culture clash at Rover when BMW took over the company from British Aerospace. Research has shown that the globalisation of business across national and cultural boundaries has resulted in some culture-clashes and there has also been an increase in interest in the impact of culture on business. This paper explains the breakdown in communication and the different approaches to car manufacturing in Rover under BMW's ownership.

Both Rover and BMW were symbols of national pride and therefore deeply embedded in their own culture. When BMW took over the Rover group, the company was making profits and Rover had won numerous quality awards. Six years later, BMW decided to sell Rover at a substantial loss but retained the new mini which has been very successful. Although some of the problems faced by BMW were outside their control, the culture clash certainly exacerbated the problem.
\end{abstract}

Keywords: Management, Culture, Rover, BMW

\section{Introduction}

This paper examines the culture clash at Rover when BMW took over the company from British Aerospace. Research has shown that the globalisation of business across national and cultural boundaries has resulted in an increase in cultureclashes and there has been an increase in interest in the impact of culture on business. This paper explains the breakdown in communication and the different approaches to car manufacturing in Rover under BMW's ownership.

Both Rover and BMW were symbols of national pride and therefore deeply embedded in their own culture. When BMW took over the Rover group, the company was making profits and Rover had won numerous quality awards. Six years later, BMW decided to sell Rover at a substantial loss but retained the new mini which has been very successful. Although some of the problems faced by BMW were outside their control, the culture clash certainly exacerbated the problem.

This paper examines the culture clash at Rover when BMW took over the company from British Aerospace. British Aerospace had turned the company around since the purchase of Rover from the government and the company had also been hailed as the learning business. When BMW took over there was a culture clash and the company was eventually sold to Phoenix after substantial losses.

It can be said that culture has a fundamental impact on the way that a business is run and that it is not an easy task to superimpose a management style on another company, especially in another country. Both BMW and Rover are important in their own country, deeply rooted in the British and German cultures as symbols of their national pride.

This study was carried out in order to discover the reasons for the culture clash between Rover and BMW and how they contributed to the failure of the take-over. Also how the differences in approaches between the two companies became irreconcilable, and primarily what were the lessons to be learned and how to overcome culture clashes in the future.

The aim is to look at the impact of cultural factors on the failure of BMW's management of Rover and whether there were critical factors that can be identified as causing problems. The take-over was based on achieving economies of scale and that combining the two companies would benefit both BMW and Rover because it would give the combined company a bigger market share. This question is how can an efficient management such as BMW lose its effectiveness when transferred across national and cultural boundaries.

This paper also looks at the way that cultural diversity can have an impact on communication, human resources, research and development, and other key areas. The problems of communicating in a different language, training, sharing information and knowledge and telephone conversations can all be affected, particularly when the business in question is based on engineering and technology. This paper tries to explain the reasons for the failure of the take-over, and the different cultural approaches to management.

This study aims to discover the importance of cultural factors in applying management techniques from one country to another. Successful international organisations have managed to overcome cultural diversity in a variety of ways. This 
paper looks at the way in which Rover managed to turn itself around by re-inventing itself as a learning organisation and how that contributed to the culture clash with BMW.

\section{Corporate Culture}

The globalisation of business across national and cultural boundaries will result in an increase in culture-clashes. FreyRidgway (1997) notes that differences in management style and organisational behaviour can often be traced back to cultural influences. There has been an increase in interest in the impact of culture on business (Hofstede, 1993, Trompenaars, 1995). Hofstede (1993) notes that management practices differ throughout the world and may deviate considerably from the American model.

Culture shapes people's sense of identity and affects their behaviour and differences in management style and organisational can be traced back to cultural diversity (Frey-Ridgway, 1997). Culture can have an underlying impact on management, and can shape identity, attitudes and behaviour.

Hofstede (1993) outlines the dimensions of culture as power distance, individualism, masculinity and uncertainty. All societies are unequal but some are more equal than others. Power distance can be defined as the degree of inequality among people, from relatively equal which can be described as a small power distance, to extremely unequal i.e. large power distance. Individualism is the degree to which people act as individuals rather than as groups and the opposite of individualism is collectivism. The third dimension is masculinity and its opposite is femininity. This is the degree to which masculine traits such as assertiveness, performance, success and competition prevail over the more feminine values such as quality of life, personal relationships, care for the weak and solidarity, which are associated with women's roles in society. The fourth dimension, uncertainty avoidance, can be defined as the degree to which people prefer structured rather than unstructured situations. Structured situations are those where there are clear rules about behaviour which may be unwritten and imposed by tradition. A society with strong uncertainty avoidance can be called rigid and one with a low uncertainty avoidance, flexible.

In Germany an engineering qualification is highly valued and the traditional role into top management has been from an engineering apprenticeship. German workers generally do not therefore need a manager to motivate them, but an engineer to assign them their tasks and to be technically competent. Management in the US is generally highly individualistic and short-term oriented whereas in Germany it is less individualistic (Hofstede, 1993). Also organisations in Germany represent a more structured model as opposed to the organisation as a 'market' in the US management model. This paper illustrates the cultural clashes that appeared when BMW took over Rover and tried to impose the German management culture on a company that has turned itself around from losses into profitability through encouraging learning.

This paper examines how national culture in Germany and the UK affected corporate culture in Rover and BMW and the failure to understand the differences in both national and corporate culture contributed to the problems with BMW's takeover of the Rover Group.

\section{Cultural Diversity in Business}

What is culture in a management context? Schein (1985) defines culture as the way in which a group of people solves problems. According to Hofstede (1993),

'Culture is the collective programming of the mind which distinguishes one group or category from another'.

According to Trompenaars (1993) culture comes in layers 'like an onion' and that to understand it you have to look at the different layers. An organisation may look very similar from the outside with similar functions and hierarchical structures etc. but underneath, there may be a fundamental difference in culture. This was certainly the case with Rover and BMW. On the surface, they were both car manufacturers with similar functions and hierarchies but with fundamentally different management cultures.

Cultures also have different levels and can be separated into national, corporate and professional. National culture is French or German, for example. Corporate culture is at the organisational level and people will have professional cultures.

Despite the superficial similarities in organisations there will be different approaches and understanding for people from different cultures. Although culture affects all aspects of the organisational culture, management processes and attitudes often fail to take these into account. An example of this was EuroDisney where initially the French staff failed to accept the American culture that was being imposed on them.

The layers of culture start with explicit products such as buildings, language, food, dress etc. The middle layer is the norms and values of the culture. Norms can include legal and social frameworks, politics and religion. The core of the onion is the basic assumptions of how people live their out lives, often based on historical and geographical factors. As people have developed in different geographical conditions, for example, they have evolved a different way of surviving.

According to Geertz (1973) culture is the means by which people communicate and develop their knowledge. However, even within different cultures there are differences but often it is the differences rather than the similarities which are noticed and these often lead to stereotypes which exaggerate and caricaturises cultural differences. 


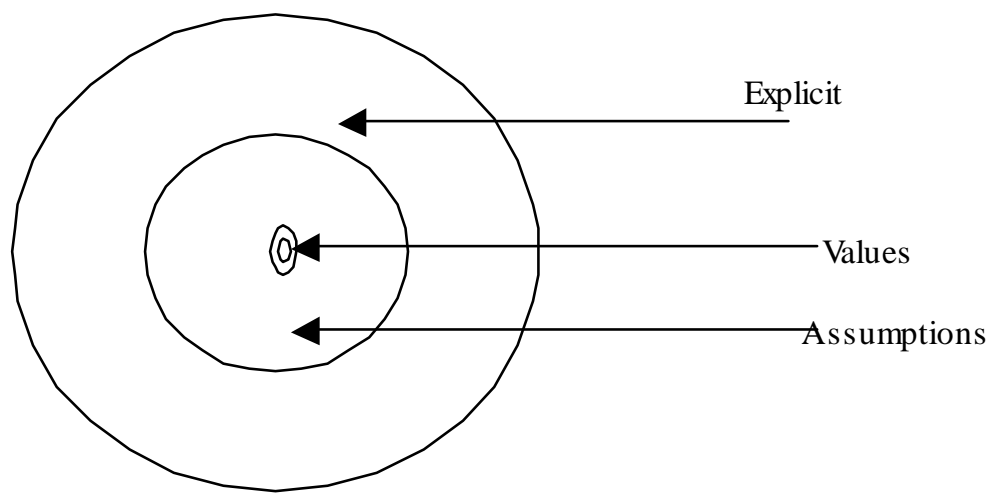

Figure 1. Layers of culture

(Adapted from Trompenaars, 1993)

Language is a clear illustration of cultural differences and other non-verbal forms of greeting and touching can be different in different cultures. German culture relies on formal structures and any changes have to be formalised than agreed as in British organisational culture (Hampden-Turner, 1991). These differences in culture between the British and German national and management cultures, as well as a different language, caused some fundamental problems for BMW when they decided to take over the Rover group. The next section looks at the learning organisation culture, which was developed in the Rover Group prior to the take-over.

\section{Background}

In the late 1980's losses at the Rover group were $£ 100$ million a year, quality was low and employee morale was getting lower. By 1996, the situation had been turned around. The company was making profits, international sales had doubled and Rover had won numerous quality awards. The new Range Rover and the Rover 600 were selling well. By 1994 profits were $£ 56$ million a year. Both top management and employees attributed the turnaround to Rover's learning organisation initiatives.

The Rover Learning Business (RLB) was created as a company within a company in 1990. Graham Day stated that the company had to learn if it was to compete globally. The RLB was to provide a new culture for Rover, a learning culture and this was to transform the company from its previous 'resistant to change' culture into a fast learning 'success through people' culture (Taylor, 1997).

When BMW purchased Rover there were concerns that the last British volume car manufacturer was to be sold. Rover was the largest single employer in the West Midlands with 33,000 employees, of whom 22,000 were employed in Solihull and Longbridge.

The advantages for BMW were seen as the ability to enter new market segments and increase its share of the European car market considerably. BMW also acquired expertise in small front-wheel drive vehicles and the cars could be sold under the Rover name, avoiding the dilution of the BMW brand image (Miller, 1994). BMW wanted to gain four-wheel drive capability as it was one of the fastest growing segments of the market. Range Rover, a strong brand name in the luxury end of the market, would be sold through BMW's networks. The advantages for Rover included investment in technology and engineering.

\section{Research Method}

The case method was chosen for this study as it provides the opportunity to gain an in-depth understanding of the impact of cultural diversity facing the management of BMW following its take-over of Rover. Yin (1994) states that the single case study can be used to observe and analyse in greater depth than would be possible with any other method. In addition, given the fact that Rover was the only remaining British mass car manufacturer prior to the take-over, and that BMW was German, the circumstances were therefore unique. Extensive interviews were conducted with one of the founders of the Rover Learning Business. A lifelong Rover employee, he saw at first hand the many changes that Rover went through, particularly the take-overs by BAe and BMW.

\section{Rover}

Rover made its first car in 1904 and then became part of British Motor Holdings. British Motor Holdings and Leyland merged in 1968 to become British Leyland, which included Austin, Jaguar, Land Rover, Morris, Triumph and Wolseley as well as Rover. By 1973 the successful Leyland Truck division was supporting the losses in the car division. In 1975 the government nationalised British Leyland. British Leyland continued to make losses and Margaret Thatcher brought in Graham Day. Day sorted out the production problems and moved Rover upmarket with Honda's support. The truck division was sold to DAF and the buses to Volvo, the spare parts to Unipart to a financial group and Rover to BAE. The successful alliance with 
Honda meant that Rover increased sales by $15 \%$ in the early 1990's. This was partly due to the success of Land Rover as the four-wheel drive market grew. The Rover 400, 600 and 800 were basically Honda's and the strategic alliance between Rover and Honda was very successful.

Rover and Honda signed a licensing agreement in 1978 and in 1988 British Aerospace bought the Rover Group in 1988. British Aerospace agreed not to sell Rover until 1993. The recession in the early 1990's affected Rover and they reported losses of $£ 8$ million in February 1992 including a $£ 45$ million write-off as a result of withdrawing from the US market (Potter, 1995). In 1992, George Simpson, the MD of Rover started a major re-structuring of the business based on Japanese HRM principles which included a 'jobs for life' guarantee. Honda's $20 \%$ involvement helped it move up-market but it was considered too small to operate as an independent manufacturer. By 1993 the alliance with Honda had led to an improvement in quality and Honda was able to sell the Discovery as the Honda Crossroad in Japan.

In 1989 Rover's George Simpson declared a new vision for the Rover group 'to become internationally renowned for extraordinary customer satisfaction'. The company had been operating for decades previously without a vision and this one surprisingly had nothing to do with cars. The vision had been prepared after a long consultation process involving hundreds of people. A two-day workshop was organised to decide how to deliver this vision and four objectives were articulated as part of this vision. The objectives were as follows:

(1) Quality. To be in the first three of league tables of European manufacturers, in a quality league in each product sector e. g. small cars.

(2) Exports. To become internally renowned and sell $50 \%$ of vehicles abroad.

(3) Costs. To reduce costs by $30 \%$. If costs could be reduced by $30 \%$ when the company would make bigger profits.

(4) Image and Reputation. Rover wanted to change the market niche from the one they were in and go up-market to compete with Saab and Volvo.

At this event, fourteen project teams were put together to achieve these objectives.

'These objectives were considered so ambitious that the majority of people thought we would never do it.'

Each project team was linked to a strategic initiative and was led by a main board director. Each director assembled their or her own project team. The idea was that progress would be achieved through people and that people were the key to achieving these objectives.

The idea was to develop the Rover Learning Business as a business within a business, to develop the learning culture. The idea started from 3 people and was to be applied to 40,000. By 1997, the Rover Group was acknowledged as a leader in the field and given an award for the best learning business. The name of the project was changed from Progress Though People to Success Through People at the board meeting in November 1989. This strategic initiative was the first to go public. Graham Day was the Chairman of the Rover Group in 1989.

One of the keys to the success of the Rover Learning Group was that all the employees had two employers, Rover and the Rover Learning Group. The Rover Learning Group was a business within the business, a subsidiary for motivating and implementing the learning culture. Initially, only three people were involved in the idea and the concept had to be rolled out to 40,000. The whole process took approximately nine months.

Another key factor was the involvement of key people. The Rover Learning Group was approved at the Rover main board in November 1989. The title of the project was 'Success Through People'. The previous board issue had been the poor quality of Range Rover in the USA, which had necessitated a lot of rectification work. The Board members were not in a mood to consider new projects but there was agreement in principle to the idea. All the main board members were invited to be on the executive operating committee to build the infrastructure within the company. Key managers such as the manufacturing director at Longbridge and the Managing Director of the parts division were involved in the project.

The support of Sir Graham Day, the chairman of the Rover Group, was also crucial to the success of the project. When Day launched the scheme in a speech to the city in March 1990 he introduced the project by stating what he had found when he came to the UK on the state of training in the UK and what Rover was going to do. Day also agreed to chair the Rover Learning Group. This was considered very important to the credibility of the Rover Learning Group. As one person said,

'As soon as he said yes, everyone in the company knew this was important because Graham Day does not back losers'.

The Rover Learning Business was credited with the change from the situation when British Aerospace bought Rover in 1988 for $£ 150$ million to six years later when BMW bought Rover for $£ 800$ million. In addition, BMW also took on Rover’s debts. In 1988 no one else made an offer for Rover and the government offered 'sweeteners' to BAe to take over the company. Six years later, several companies were interested in Rover and BMW brought the company in a take-over which took everyone by surprise, including Honda, Rover's partner.

The reason for the turnaround in the company's fortunes in the six years during BAe's ownership was achieving change through people. Rover could not afford to invest in new technology so the only thing they could invest in was the people 
who worked for the company.

'The only thing we could invest in was the people because we did not have enough to invest in anything else'.

The company started making a profit after many years of making substantial losses. Very little was invested in systems or capital equipment. The main investment was in people's time. The Rover Learning Business was the focal point of this investment.

\section{Rover Learning Business}

Learning organisations focus on learning, which challenges existing values, procedures and knowledge to develop a new organisational model. According to Henderson (1997), the problem with organisational learning is that it focuses on overcoming learning obstacles. However, if learning obstacles were overcome, managers would be inundated with the latest management techniques and would therefore become less efficient.

What is a learning organisation? A learning organisation is one that improves performance through learning, invests in education and training and encourages people to fulfil their potential (Taylor, 1997). Other characteristics of a learning organisation include the communication of its vision for the future, and encouraging its employees to improve quality and continuous innovation.

'If the company seeks to survive and prosper, it must learn' (Graham Day, Chairman, Rover Group).

It was recognised that the key to achieving Rover's four strategic objectives was through the people who worked for Rover. The success of the RLB was that it changed the culture within Rover. Profits and turnover per person increased and warranty costs were reduced. Rover became acknowledged as a world leader in organisational learning and received several awards. This expertise was recognised by other countries and organisations and representatives from RLB went all over the world to help them create a learning culture so that they could implement change.

The board members of the Rover Learning Business were all influential people. The included Sir Graham Day, the Chairman of the Rover group, Baroness Blackstone, Principal of Birkbeck College and Minister for Lifelong Learning, the Hon. Sarah Morrison, main board member of GEC, George Bain, the principal of the London Business School, Professor Charles Bahn, City University, New York, Professor Peter Toyne, Vice Chancellor of Liverpool John Moores University and Derek Gladwin, now Lord Gladwin, a senior union official.

The Rover Learning Business was linked to the quality strategy. This was outlined on one sheet of A3 paper, which included the vision, business objectives, and accountability for the Quality Strategy including the nine main business processes. The nine business processes were chosen as the ones that would add the most value for achieving the business objectives. Included in the nine business processes was one on Corporate Learning. Each of the nine business processes was identified as either a primary driver or a related driver to the four business objectives. Corporate Learning was one of three business processes that was a primary driver to all the business objectives.

The definition of Corporate Learning used by Rover was 'the process by which growth is managed through people who want or need to learn'. The vision for Corporate Learning was to become the 'world best learning company' by the end of 1995. Actions for individuals included $£ 100$ for any employee to learn about the subject of their own choice, which was nonvocational. This was known as REAL - Rover Employee Assisted Learning. Each employee also had their own personal development plan agreed with his or her line manager. Employees were also encouraged to use their own preferred learning style and to keep an annual learning diary. The idea was that everyone would learn in an environment conducive to learning and on subjects which would improve the performance of the business.

The purpose of the Rover Learning Business was to create an environment for continuous learning and have a leadership role for the corporate learning process within the Rover Group's quality strategy. The Rover Learning Business fulfilled this role in Rover until the BMW take-over.

Improving quality was essential for Rover and the principles of corporate learning were based on those of Total Quality Management including the following:

(1) Continuous improvement

(2) Management led

(3) Everyone responsible for quality

(4) Company-wide

(5) Cost of Quality

( Source: Taylor, 1997)

One of the fundamental aspects of the Corporate Learning initiative was that the top management were meant to be fully involved. Each of the Rover Group members was to participate in the Rover Learning Business. The Rover Learning Business was based on simple procedures and a lack of bureaucracy. The underlying philosophy of Rover Learning was 'success through people'. Employees were encouraged to take responsibility for their own learning and development. Each 
Rover site was fitted with open learning facilities, which were open to all employees. The change in emphasis from the late 1980's and early 1990's was from a 'training' culture to a 'learning' culture (Taylor, 1997). RLB's mission was to create a culture of 'continuous learning' within Rover in order to achieve its business objectives. The training departments were renamed the training and development departments and Rover was awarded the title 'world learning organisation' in Canada in 1997.

\section{BMW and Rover}

BMW was still profitable in the early 1990's but like Rover, it was too small and the company needed to expand its range to compete with the larger manufacturers. BMW was particularly interested in Land Rover, and Rover's four wheel-drive capability. Honda had the first option to buy the remaining equity in Rover. In 1994, BMW made an offer to buy Rover for $£ 800$ million and take on a $£ 900$ million in net debt and off balance sheet finance. Honda was offered $51 \%$ of Rover but refused and subsequently the managers were very upset about the BMW deal. BAe had put its shareholders first but Honda felt that their trust had been betrayed (Potter, 1995). Pischetsreider, the Chairman of BMW, wanted to turn Rover into a strong and exclusive brand like BMW.

In the 1990's Rover had a strong brand image as 'the ultimate driving machine' and BMW was the car of the yuppies in the 1980's (HBS, 1993). The brand was promoted as a performance car at a reasonable price that retained its value and second hand car prices were maintained. BMW emphasised quality and performance in its advertisements and offered a range of models and prices in terms of prestige and size. BMW cars were sold on the basis of the engineering. BMW exported most of its cars and exports rose from 70\% of sales in 1995 to $80 \%$ in 1997 (Potter, 1998).

After the acquisition of Rover, BMW planned an investment of $£ 500$ million per year in the UK in order to counteract the decades of low investment in plant and machinery (Potter, 1998). By October 1996 all key management and marketing positions within Rover were filled with BMW personnel. BMW also planned to rationalise the operational aspects of BMW and to merge the supplier networks and engineering activities whilst at the same time increasing Rover sales to 800 cars per annum. The idea was to combine BMW's high technology approach to car manufacturing to Rover's appeal for lifestyle. In 1996 Rover launched the Freelander, the new small Land Rover. BMW also announced plans to invest $£ 400$ million in a new engine plant in the UK. In 1996, Rover exported 50\% of sales but made losses of $£ 100$ million.

John Towers was the Managing Director of Rover after the BMW take-over, Bert Pischetsreider was the Chairman of BMW and Rover. He wanted the company to work together and to learn from each other. BMW had six main committees to organise the company. None of the six committees were on people. They were on things such as purchasing and engineering. Bert Pischetsreider tried to impose a different culture on Rover. John Towers wanted to introduce BMW to Rover Learning. Bert Pischetsreider only visited Rover once a month but John Towers took him to the Rover Learning Business to meet the board members.

After eighteen months Bert Pischetsreider stepped down as Chairman and Wolfgang Reisler, the second in command at BMW, was appointed Chairman. John Towers left Rover but he remained Chairman of Rover Learning Business until 1996. BMW appointed Walter Hasselkiss as Chief Executive. By 1997, when Hasslekiss took over, the pound had started to rise against other currencies and this posed a serious problem for Rover's exports. The customer base by now was $60 \%$ international. BMW also intended to invest heavily in engineering and the pound's strength meant that this investment would become more expensive for BMW.

By 1997 the high value of sterling was beginning to cause serious problems for BMW and the Rover could not make a profit. BMW's board started to get concerned and started calling Rover, 'the English patient'. Several of the Rover senior managers, including Pieschreider, Reisler and Hasselkiss were sacked. BMW were looking for scapegoats.

By now the culture at Rover was changing rapidly. From a hands-off management style, BMW had taken control of every decision and the company was being managed from Munich. BMW applied German management practices to Rover and insisted on total control, discipline and all instructions had to be followed to the letter.

\section{'The culture went from hands-off to down your throat.'}

One of the casualties was the Rover Learning Business, which was disbanded as a department in 1997. Rover was by this time winning awards for being a learning organisation but the losses were mounting for BMW. Joachim Miller was appointed Chairman and Chief Executive and the decision was made in to sell the company. BMW lost $£ 3$ billion and sold the company for $£ 1.8$ million, keeping the mini and the new mini.

\section{Implications}

One of the problems with German management is that HRM management has a low status (Radlesome, 2000) whereas engineering qualifications are highly regarded. The Rover approach was rooted in the Total Quality Management techniques adopted by the Japanese. Car manufacturers in Japan had adopted the TQM techniques since the 1940's and had used them to improve the quality of their cars and their management. Rover had had links with Honda and this may have reinforced the TQM approach. 
Take-overs of companies in other countries can be risky as in the case of Marks and Spencer's take-over of Brooks Brothers in the US. BMW's take-over of Rover was ambitious. On the surface, both companies were car manufacturers and there were obvious economies of scale. However, both companies were deeply rooted in their own national culture and the cars were a source of national pride.

BMW's take-over of Rover failed for a number of reasons. However, cultural factors did play an important part in this failure. The German management culture is precise and regulated whereas British management culture is less formal. Although both firms were car manufacturers, this only emphasised the difference as engineering has a high status in Germany and an engineering qualification is highly valued.

Traditionally, Rover would have been closer to BMW on Hofstede's cultural dimensions, particularly masculinity and uncertainty avoidance. Given that Anglo-Saxon culture originally came from Northern Europe and that Rover's roots were in engineering, the scale of the culture clash was probably unexpected. The development of the learning culture at Rover, however, was more feminine and unstructured which is closer to the Japanese management culture that the traditional engineering culture which prevailed at Rover before the link with Honda. It is clear that the links with Honda had a deeper effect on the culture than was apparent. The question is whether BMW's approach would have been different if they had known this. It is possible that a deeper understanding of the national and management culture at Rover would have helped BMW.

It can be concluded from this study that cultural differences, both national and managerial, can have a considerable impact on the success or failure of mergers and take-overs in different countries. International businesses such as HSBC recognise cultural diversity whereas others apparently ignore them although organisations such as McDonalds have local managers who are encouraged to join local business networks. Recognising cultural diversity is important, not only on a social level, but also in business.

\section{Conclusion}

By May 2000, Rover was in crisis. The Quandt family had decided that they could no longer sustain losses at Rover and decided the put the company up for sale. The initial buyer was Alchemy but Alchemy was viewed as an asset stripper and there were concerns that there would be severe job losses. A consortium led by Rover's former chief executive, John Towers, Phoenix, bought the company. The unions favoured the Phoenix bid because it planned to retain mass production, and although sales initially increased due to discounts and support for Rover, it failed to make a profit and went into receivership in 2005 .

BMW had decided to withdraw from Rover and to concentrate on the new mini. The strategy of concentrating on the one model appears to be working with sales doing well, although there were initial losses. BMW decided to build a new manufacturing plant and start from scratch rather than build at Longbridge and face the same problems as before. This was expensive but now BMW but the new mini has been a success. BMW's current strategy is to grow from within rather than by acquisition.

Although some of the problems faced by BMW were outside their control, in particular the strong pound, the culture clash certainly exacerbated the problem. Rover had turned the company around by investing and empowering its employees. BMW's approach was to invest in the engineering side of the business and resume total control. The overall effect was to increase losses at Rover to a level that BMW could not sustain and Rover had to be sold. BMW managed to survive the losses from the Rover take-over and turn itself around by developing new models. It is clear that cultural factors can make it difficult to impose a management style on another company, especially when it is in a different country with a different language. Taking cultural factors into account is essential if such ventures are to succeed.

\section{References}

Berkeley, N., Donnelly, T., Morris, D. \& Donnelly, M. (2005). Industrial Restructuring and the State; the Case of MG Rover', Local Economy, Vol. 20, No. 4, pp. 360-371.

Frey-Ridgway, S. (1997). The cultural dimension of international business', Collection Building, Vol. 16, No.1 pp.12-23.

Geertz, C.(1973). The Interpretation of Cultures, Basic Books, New York.

Hampden-Turner, C. ( 1991). Corporate Culture, the Economist Books, London.

Harvard Business School. (1993). BMW: The Ultimate Driving Machine Seeks to De-Yuppify Itself, Case Study 9-593-046, Harvard Business School.

Henderson, S. (1997). Black swans don't fly double loops: the limits of the learning organisation? The Learning Organisation, Vol. 4, No. 3, pp.99-105.

Hofstede, G. (1993). Cultural constraints in management theories, Academy of Management Executive, Vol.7, No.1, pp.81-94.

Miller, P. (1994). BMW - British Aerospace: The Rover Deal, IESE, Barcelona. 
Schein, E. (1987). Organisational Culture and Leadership, Jossey-Bass, San Fransisco.

Taylor, C. (1997). Celebrate and record Rover Group's drive towards extraordinary customer satisfaction. Managing Service Quality, Vol. 7., No. 4, pp.169-174.

Trompenaars, F. (1993). Riding the Waves of Culture: Understanding Cultural Diversity in Business, Nicholas Brealey Publishing.

Yin, R. K. (1994). Case Study Research: Design and Methods, Sage Publications. 